\title{
Infrared and Raman spectroscopic characterization of the carbonate mineral huanghoite - And in comparison with selected rare earth carbonates
}

\author{
Ray L. Frost ${ }^{\mathrm{a}, *}$, Andrés López $^{\mathrm{a}}$, Ricardo Scholz ${ }^{\mathrm{b}}$, Yunfei Xi ${ }^{\mathrm{a}}$, Fernanda Maria Belotti ${ }^{\mathrm{c}}$

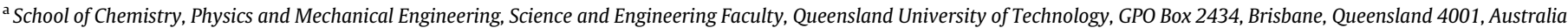 \\ ${ }^{\mathrm{b}}$ Geology Department, School of Mines, Federal University of Ouro Preto, Campus Morro do Cruzeiro, Ouro Preto, MG 35,400-00, Brazil \\ ${ }^{\mathrm{c}}$ Federal University of Itajubá, Campus Itabira, Itabira, MG, Brazil
}

\section{H I G H L I G H T S}

- We have undertaken a study of huanghoite using vibrational spectroscopy.

- A comparison is made with spectra of other halogenated carbonates.

- Multiple carbonate stretching vibrations proved that there are non-equivalent carbonate units.

- Raman bands in the $\mathrm{OH}$ stretching region gives evidence for $\mathrm{OH}$ units in the huanghoite structure.

\section{A R T I C L E I N F O}

\section{Article history:}

Received 15 May 2013

Received in revised form 15 July 2013

Accepted 26 July 2013

Available online 20 August 2013

\section{Keywords:}

Huanghoite

Carbonate

Molecular structure

Raman spectroscopy

Infrared spectroscopy

\begin{abstract}
A B S T R A C T
Raman spectroscopy complimented with infrared spectroscopy has been used to study the rare earth based mineral huanghoite with possible formula given as $\mathrm{BaCe}\left(\mathrm{CO}_{3}\right)_{2} \mathrm{~F}$ and compared with the Raman spectra of a series of selected natural halogenated carbonates from different origins including bastnasite, parisite and northupite. The Raman spectrum of huanghoite displays three bands are at 1072, 1084 and $1091 \mathrm{~cm}^{-1}$ attributed to the $\mathrm{CO}_{3}^{2-}$ symmetric stretching vibration. The observation of three symmetric stretching vibrations is very unusual. The position of $\mathrm{CO}_{3}^{2-}$ symmetric stretching vibration varies with mineral composition. Infrared spectroscopy of huanghoite show bands at 1319, 1382, 1422 and $1470 \mathrm{~cm}^{-1}$. No Raman bands of huanghoite were observed in these positions. Raman spectra of bastnasite, parisite and northupite show a single band at 1433,1420 and $1554 \mathrm{~cm}^{-1}$ assigned to the $v_{3}\left(\mathrm{CO}_{3}\right)^{2-}$ antisymmetric stretching mode. The observation of additional Raman bands for the $v_{3}$ modes for some halogenated carbonates is significant in that it shows distortion of the carbonate anion in the mineral structure. Four Raman bands for huanghoite are observed at 687, 704, 718 and $730 \mathrm{~cm}^{-1}$ and assigned to the $\left(\mathrm{CO}_{3}\right)^{2-} v_{2}$ bending modes. Raman bands are observed for huanghoite at around $627 \mathrm{~cm}^{-1}$ and are assigned to the $\left(\mathrm{CO}_{3}\right)^{2-} v_{4}$ bending modes. Raman bands are observed for the carbonate $v_{4}$ in phase bending modes at $722 \mathrm{~cm}^{-1}$ for bastnasite, 736 and $684 \mathrm{~cm}^{-1}$ for parisite, $714 \mathrm{~cm}^{-1}$ for northupite. Raman bands for huanghoite observed at 3259,3484 and $3589 \mathrm{~cm}^{-1}$ are attributed to water stretching bands. Multiple bands are observed in the $\mathrm{OH}$ stretching region for bastnasite and parisite indicating the presence of water and $\mathrm{OH}$ units in their mineral structure. Vibrational spectroscopy enables new information on the structure of huanghoite to be assessed.
\end{abstract}

() 2013 Elsevier B.V. All rights reserved.

\section{Introduction}

The carbonates are a group of over 150 naturally occurring minerals containing the essential structural building block $\left(\mathrm{CO}_{3}\right)^{2-}$. Most of these minerals are relatively rare and quite often in association with other building blocks such as hydroxyls, halogens, sulfate, silicate, and phosphate. Among these minerals is the carbonate mineral huanghoite $\mathrm{BaCe}\left(\mathrm{CO}_{3}\right)_{2} \mathrm{~F}$. The mineral is one of

\footnotetext{
* Corresponding author. Tel.: +61 73138 2407; fax: +61 731381804

E-mail address: r.frost@qut.edu.au (R.L. Frost).
}

the synchysite mineral group which includes synchysite-Ce $\mathrm{Ca}(\mathrm{Ce}, \mathrm{La})\left(\mathrm{CO}_{3}\right)_{2} \mathrm{~F}$, synchysite- $\mathrm{Nd} \mathrm{Ca}(\mathrm{Nd}, \mathrm{Y}, \mathrm{Gd})\left(\mathrm{CO}_{3}\right)_{2} \mathrm{~F}$, synchysite- $\mathrm{Y}$ $\mathrm{Ca}(\mathrm{Y}, \mathrm{Ce})\left(\mathrm{CO}_{3}\right)_{2} \mathrm{~F}$. The importance of these rare earth minerals is that the minerals are a source of rare earths including lanthanum, yttrium and cerium.

There are a number of halogen containing carbonates including bastnaesite (often written as bastnasite and bastnäsite) $\left[(\mathrm{Ce}, \mathrm{La}) \mathrm{CO}_{3} \mathrm{~F}\right]$, parisite $\left[\left(\mathrm{Ce}_{2}, \mathrm{Ca}\right)\left(\mathrm{CO}_{3}\right) \mathrm{F}_{2}\right]$, northupite $\left[\left(\mathrm{Na}_{2}\right.\right.$, $\mathrm{Mg})\left(\mathrm{CO}_{3}\right)_{2} \mathrm{~F}$, and phosgenite $\left[\mathrm{Pb}_{2} \mathrm{CO}_{3} \mathrm{Cl}\right]$ [1]. In fact this group of minerals supplies more than $70 \%$ of the world's supply of rare earths. In addition minerals based upon hydroxbastnasite are also 
known but little or no information is available for this mineral $[2-4]$. It is probable that the mineral decrespignyite- $(\mathrm{Y})$ is structurally related to bastnäsite-synchysite-parsite group all of which adopt a hexagonal or at least a pseudohexagonal layered structure based upon repeat units of $\mathrm{REE}-\mathrm{CO}_{3}^{2-}(\mathrm{F}, \mathrm{OH})$ [5-7]. Bastnäsite is one of three carbonate-fluoride minerals. There is bastnäsite-(Ce) with a formula of $(\mathrm{Ce}, \mathrm{La}) \mathrm{CO}_{3} \mathrm{~F}$. There is bastnäsite-(La) with a formula of ( $\mathrm{La}, \mathrm{Ce}) \mathrm{CO}_{3} \mathrm{~F}$. There is also bastnäsite-(Y) with a formula of $(\mathrm{Y}, \mathrm{Ce}) \mathrm{CO}_{3} \mathrm{~F}$. Most bastnäsite is bastnäsite-(Ce), and cerium is by far the most common of the rare earths in this class of minerals. Bastnäsite is closely related to the mineral parisite; both are rare earth fluorocarbonates. Parisite formula varies depending upon the locality of origin and may be generalized as $\left[\mathrm{Ca}(\mathrm{Ce}, \mathrm{La}, \mathrm{Nd})_{2}(-\right.$ $\left.\mathrm{CO}_{3}\right) \mathrm{F}_{2}$ ]. Bastnasite forms a series with the mineral hydroxybastnasite. This latter mineral has a formula $\left[(\mathrm{Ce}, \mathrm{La}) \mathrm{CO}_{3}(\mathrm{OH}, \mathrm{F})\right]$ in which hydroxyl units substitute for the fluorine.

The crystal structures of most halogenated carbonates have been studied [8-10] including huanghoite [11-14]. However the crystal structure of decrespignyite is not known or defined. The crystal structure of parisite is said to be rhombohedral but the structure depends on the composition and origin of the mineral $[8,15-19]$. The infrared spectra of bastnasite, parisite and northupite have been published [20,21]. According to Farmer [1], bastnasite is hexagonal and the carbonate units lie on the $6(\mathrm{~h})$ sites with point symmetry $C_{s}$. The internal modes of the carbonate ion are symmetrical with little evidence of splitting. In the infrared spectra, the only evidence of symmetry reduction is the appearance of a low intensity band in the $v_{1}$ position. The infrared spectra of parisite has been said to show low site symmetry and the presence of more than one carbonate type in the unit cell. Adler and Kerr observed splitting of $v_{1}$ and $v_{4}$ vibrational modes [20]. Farmer states that northupite has a highly symmetrical structure and is a rare example of a carbonate with a cubic structure [1]. The structure is complex with 16 formula units in the face-centred cubic cell. As a consequence of the reduction in symmetry from $D_{3 h}$ to $C_{3}$, all bands are both infrared and Raman active.

Raman spectroscopy has proven most useful for the study of diagenetically related minerals as often occurs with carbonate minerals [22-24].

The objective of this paper is to report the vibrational spectroscopic study of a huanghoite mineral and relate the spectra to the molecular chemistry and the crystal chemistry of this carbonate mineral. We have characterized huanghoite using Raman and infrared spectroscopy, with support of scanning electron microscopy in the mineral characterization.

\section{Experimental}

\subsection{Samples description and preparation}

The huanghoite sample studied in this work was obtained from the collection of the Geology Department of the Federal University of Ouro Preto, Minas Gerais, Brazil, with sample code SAB-116. The sample is from the type locality for the mineral, the Bayan Obo deposit, Inner Mongolia Autonomous Region, China [25]. The mineral occurs in association with aegirine.

The sample was gently crushed and the associated minerals were removed under a stereomicroscope Leica MZ4. Scanning electron microscopy (SEM) was applied to support the mineralogical characterization.

\subsection{Scanning electron microscopy (SEM)}

Experiments and analyses involving electron microscopy were performed in the Center of Microscopy of the Universidade Federal de Minas Gerais, Belo Horizonte, Minas Gerais, Brazil (http:// www.microscopia.ufmg.br).

Huanghoite single crystal up to $2 \mathrm{~mm}$ was coated with a $5 \mathrm{~nm}$ Au. Secondary Electron and Backscattering Electron images were obtained using a JEOL JSM-6360LV equipment. A qualitative and semi-quantitative chemical analysis in the EDS mode was performed with a ThermoNORAN spectrometer model Quest and was applied to support the mineral characterization.

\subsection{Raman microprobe spectroscopy}

Crystals of huanghoite were placed on a polished metal surface on the stage of an Olympus BHSM microscope, which is equipped with $10 \times, 20 \times$, and $50 \times$ objectives. The microscope is part of a Renishaw 1000 Raman microscope system, which also includes a monochromator, a filter system and a CCD detector (1024 pixels). The Raman spectra were excited by a Spectra-Physics model 127 He-Ne laser producing highly polarized light at $633 \mathrm{~nm}$ and collected at a nominal resolution of $2 \mathrm{~cm}^{-1}$ and a precision of $\pm 1 \mathrm{~cm}^{-1}$ in the range between 200 and $4000 \mathrm{~cm}^{-1}$. Repeated acquisitions on the crystals using the highest magnification $(50 \times)$ were accumulated to improve the signal to noise ratio of the spectra. Raman Spectra were calibrated using the $520.5 \mathrm{~cm}^{-1}$ line of a silicon wafer. The Raman spectrum of at least 10 crystals was collected to ensure the consistency of the spectra.

\subsection{Infrared spectroscopy}

Infrared spectra were obtained using a Nicolet Nexus 870 FTIR spectrometer with a smart endurance single bounce diamond ATR cell. Spectra over the $4000-525 \mathrm{~cm}^{-1}$ range were obtained by the co-addition of 128 scans with a resolution of $4 \mathrm{~cm}^{-1}$ and a mirror velocity of $0.6329 \mathrm{~cm} / \mathrm{s}$. Spectra were co-added to improve the signal to noise ratio. The infrared spectra are given in the supplementary information.

Spectral manipulation such as baseline correction/adjustment and smoothing were performed using the Spectracalc software package GRAMS (Galactic Industries Corporation, NH, USA). Band component analysis was undertaken using the Jandel 'Peakfit' software package that enabled the type of fitting function to be selected and allows specific parameters to be fixed or varied accordingly. Band fitting was done using a Lorentzian-Gaussian cross-product function with the minimum number of component bands used for the fitting process. The Gaussian-Lorentzian ratio was maintained at values greater than 0.7 and fitting was undertaken until reproducible results were obtained with squared correlations of $r^{2}$ greater than 0.995 .

\section{Results and discussion}

\subsection{Chemical composition of huanghoite}

The SEM image of huanghoite sample studied in this work is shown in Fig. 1. The image shows a homogeneous fragment with no zonation or associated minerals. Qualitative chemical analysis shows a $\mathrm{Ba}, \mathrm{Ce}$ and $\mathrm{F}$ carbonate with minor amounts of $\mathrm{Nd}$ (Fig. 2). The observed elements via SEM/EDS are in agreement with the chemical composition of huanghoite.

\subsection{Spectroscopy of the carbonate anion}

Nakamoto et al. [26] first published and tabulated the selection rules for unidenate and bidentate anions including the carbonate anion. The free ion, $\mathrm{CO}_{3}^{2-}$ with $D_{3 \mathrm{~h}}$ symmetry exhibits four normal vibrational modes; a symmetric stretching vibration $\left(v_{1}\right)$, an 


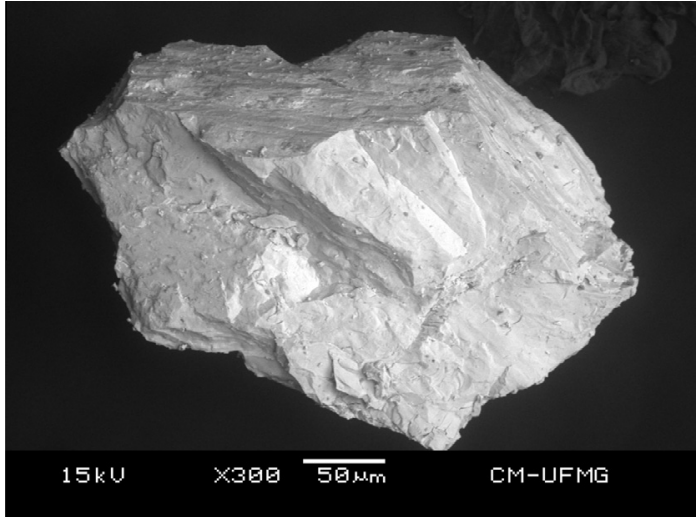

Fig. 1. Backscattered electron image (BSI) of a huanghoite crystal up to $0.5 \mathrm{~mm}$ in length.

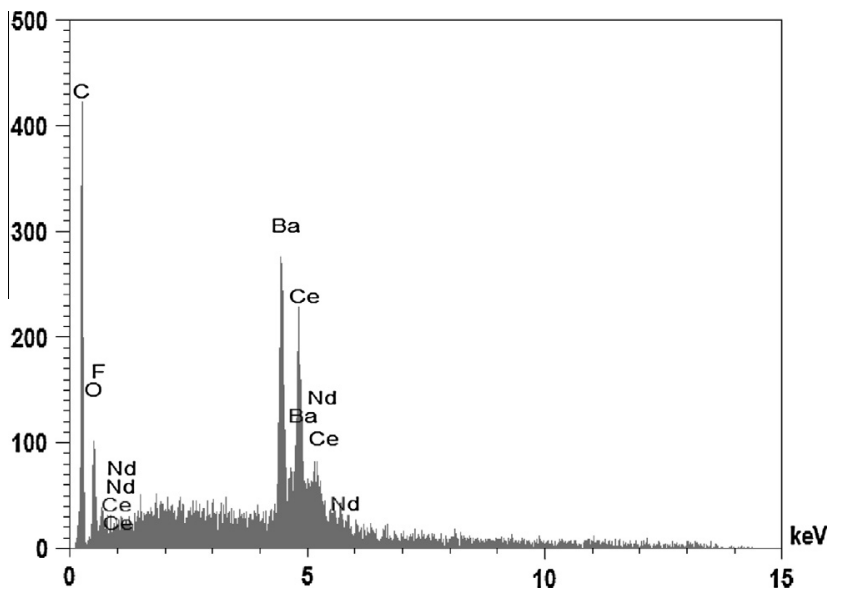

Fig. 2. EDS spectra of huanghoite.

out-of-plane bend $\left(v_{2}\right)$, a doubly degenerate asymmetric stretch $\left(v_{3}\right)$ and another doubly degenerate bending mode $\left(v_{4}\right)$. The symmetries of these modes are $A_{1}^{\prime}(R)+A_{2}^{\prime \prime}(I R)+E^{\prime}(R, I R)+E^{\prime \prime}(R, I R)$ and occur at $1063,879,1415$ and $680 \mathrm{~cm}^{-1}$ respectively. Generally, strong Raman modes appear around $1100 \mathrm{~cm}^{-1}$ due to the symmetric stretching vibration $\left(v_{1}\right)$, of the carbonate groups, while intense IR and weak Raman peaks near $1400 \mathrm{~cm}^{-1}$ are due to the antisymmetric stretch $\left(v_{3}\right)$. Infrared modes near $800 \mathrm{~cm}^{-1}$ are derived from the out-of-plane bend $\left(v_{2}\right)$. Infrared and Raman modes around $700 \mathrm{~cm}^{-1}$ region are due to the in-plane bending mode $\left(v_{4}\right)$. This mode is doubly degenerate for undistorted $\mathrm{CO}_{3}^{2-}$ groups. As the carbonate groups become distorted from regular planar symmetry, this mode splits into two components. Infrared and Raman spectroscopy provide sensitive test for structural distortion of $\mathrm{CO}_{3}^{2-}$.

\subsection{Spectroscopy}

The Raman spectrum of huanghoite in the $100-4000 \mathrm{~cm}^{-1} \mathrm{spec}-$ tral range is displayed in Fig. 3a. This figure shows the position and relative intensities of the Raman bands. There are large parts of the spectrum where no intensity is observed and thus, the spectrum is divided into sections depending upon the type of vibration being studied. The infrared spectrum of huanghoite over the 500$4000 \mathrm{~cm}^{-1}$ spectral range is shown in Fig. 3b. Again, there are large parts of the spectrum where no intensity is observed, and the spectrum may be subdivided into sections according to the type of vibration being examined.
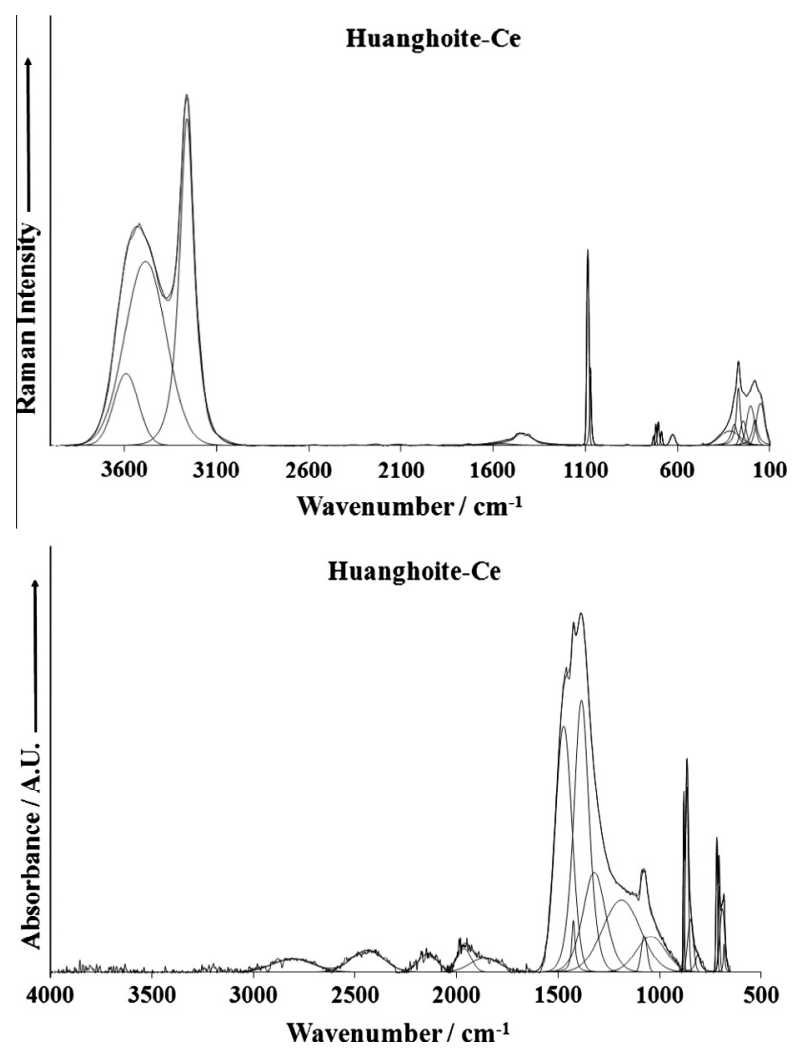

Fig. 3. (a) Raman spectrum of huanghoite over the $100-4000 \mathrm{~cm}^{-1}$ spectral range. (b) Infrared spectrum of huanghoite over the $500-4000 \mathrm{~cm}^{-1}$ spectral range.

The Raman spectrum of huanghoite in the $800-1400 \mathrm{~cm}^{-1}$ spectral range is displayed in Fig. 4a. The spectrum is dominated by a very intense sharp band at $1084 \mathrm{~cm}^{-1}$ assigned to the $\mathrm{CO}_{3}^{2-} \mathrm{v}_{1}$ symmetric stretching mode. The main band has shoulders at 1072 and $1091 \mathrm{~cm}^{-1}$. Low intensity Raman bands are found at 1350,1371 and $1385 \mathrm{~cm}^{-1}$. These bands are attributed to the $\mathrm{CO}_{3}^{2-} \mathrm{v}_{3}$ antisymmetric stretching modes. In the infrared spectrum shown in Fig. $4 \mathrm{~b}$, the $\mathrm{CO}_{3}^{2-} v_{1}$ symmetric stretching mode is observed as a number of bands at 1057 and $1065 \mathrm{~cm}^{-1}$ with shoulder bands at 1048, 1072 and $1080 \mathrm{~cm}^{-1}$.

The Raman spectra of huanghoite in the $500-800 \mathrm{~cm}^{-1}$ spectral range and in the $100-500 \mathrm{~cm}^{-1}$ spectral range are illustrated in Fig. 5. Four Raman bands for huanghoite are observed at 687, 704,718 and $730 \mathrm{~cm}^{-1}$ and assigned to the $\left(\mathrm{CO}_{3}\right)^{2-} v_{2}$ bending modes. Raman bands are observed for huanghoite at 619,632 and $635 \mathrm{~cm}^{-1}$ and are assigned to the $\left(\mathrm{CO}_{3}\right)^{2-} v_{4}$ bending modes. Raman bands are observed for the carbonate $v_{4}$ in phase bending modes at $722 \mathrm{~cm}^{-1}$ for bastnasite, 736 and $684 \mathrm{~cm}^{-1}$ for parisite, $714 \mathrm{~cm}^{-1}$ for northupite. The Raman spectrum in the far low wavenumber region (Fig. 5b) shows a broad spectral feature which may be resolved into component bands at 150,181, 244, 270, $292 \mathrm{~cm}^{-1}$. These bands are simply described as lattice vibrations.

The Raman spectrum of huanghoite in the $2800-3800 \mathrm{~cm}^{-1}$ spectral range is reported in Fig. 6. Raman bands are observed at 3259,3484 and $3589 \mathrm{~cm}^{-1}$. These bands are attributed to water stretching vibrations. The observation of water bands in the Raman spectrum of huanghoite is unexpected as the formula suggests that no water is present.

A comparison may be made with the hydroxyl stretching region of the other halogenated minerals.

The Raman spectrum of bastnasite displays bands in similar positions at $3651,3620,3526,3355,3276,3169$ and $3203 \mathrm{~cm}^{-1}$. The three higher wavenumber bands $\left(3651,3620,3526 \mathrm{~cm}^{-1}\right)$ 

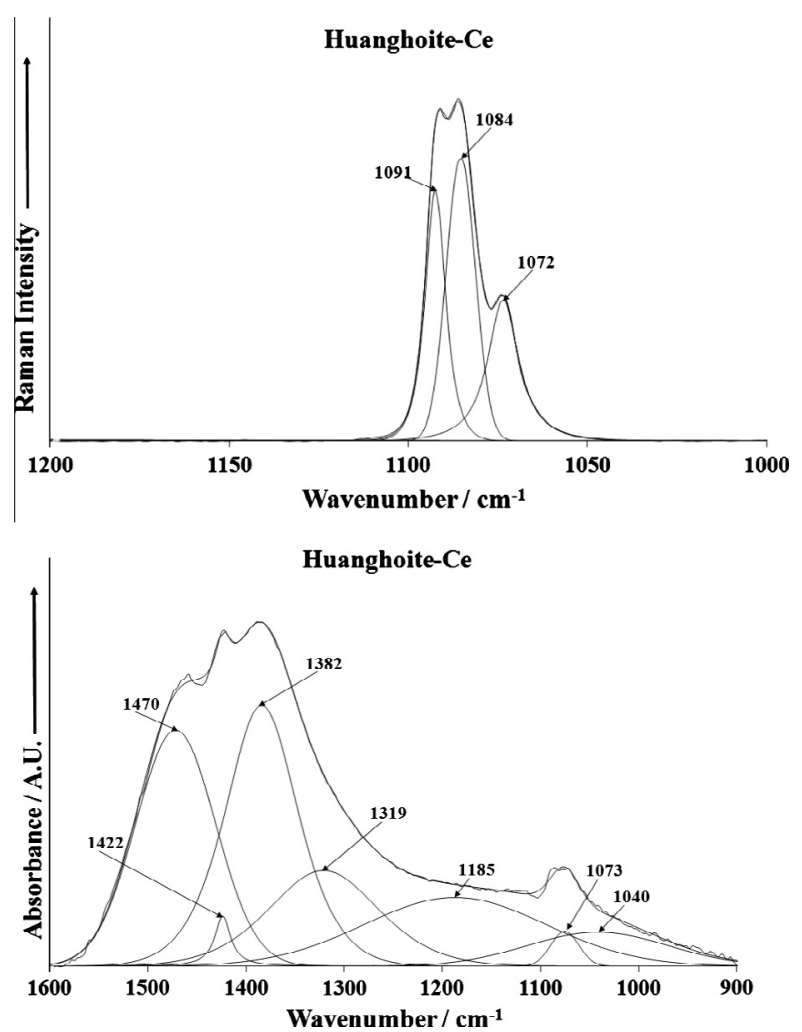

Fig. 4. (a) Raman spectrum of huanghoite over the $800-1400 \mathrm{~cm}^{-1}$ spectral range. (b) Infrared spectrum of huanghoite over the $500-1300 \mathrm{~cm}^{-1}$ spectral range.
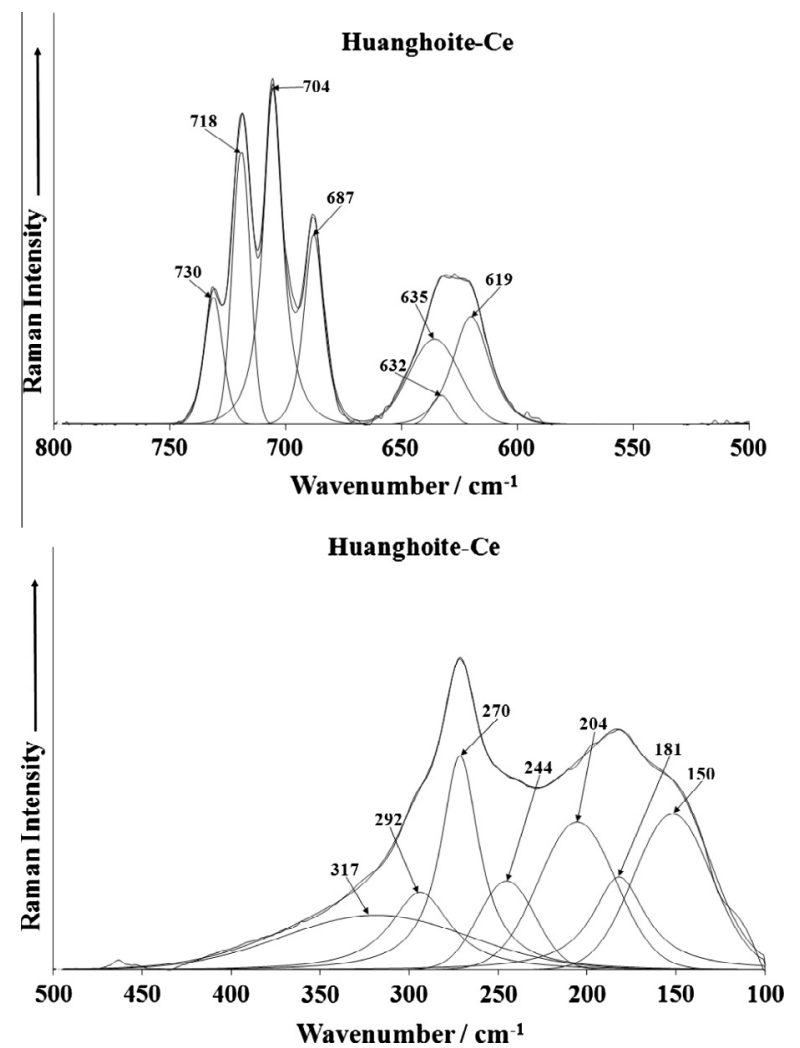

Fig. 5. (a) Raman spectrum of huanghoite over the $300-800 \mathrm{~cm}^{-1}$ spectral range. (b) Raman spectrum of huanghoite over the $100-300 \mathrm{~cm}^{-1}$ spectral range.

are most likely assignable to $\mathrm{OH}$ stretching vibrations. Raman spectra of a Chinese bastnasite have been published but no spectral

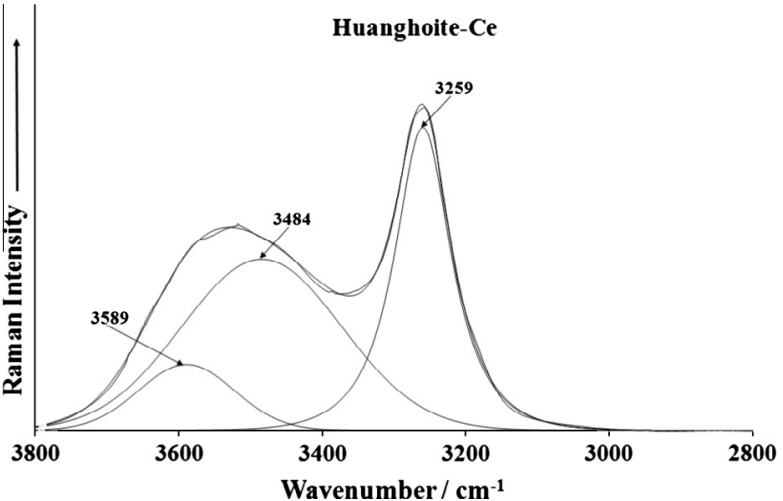

Fig. 6. (a) Raman spectrum of huanghoite over the $2600-4000 \mathrm{~cm}^{-1}$ spectral range. (b) Infrared spectrum of huanghoite over the $2600-4000 \mathrm{~cm}^{-1}$ spectral range.

information is available for comparison in this spectral region [27]. Another study reported some Raman data for rare earth carbonates [28,29]. However no spectral information in the $\mathrm{OH}$ stretching region was reported. The Raman spectrum of the hydroxybastnasite shows several bands at 3741, 3535, 3430, 3352 and $3317 \mathrm{~cm}^{-1}$. For this mineral $\mathrm{OH}$ units replace $\mathrm{F}$ in a complex structure. It is possible that all of this set of bands is attributable to $\mathrm{OH}$ stretching vibrations. Aleksandrov described two types of bastnasites namely fluorobastnasite and hydroxybastnasite [29]. Another paper described the IR spectra in this spectral region with no detail except to state bands were observed [4]. For the mineral parisite broad bands in the $\mathrm{OH}$ stretching region are observed. Four Raman bands are observed at 3661, 3517, 3316 and $3180 \mathrm{~cm}^{-1}$.

\section{Conclusions}

Raman spectroscopy has been used to characterize the mineral huanghoite and a comparison made with other halogenated carbonates including bastnasite, hydroxybastnasite, parisite and northupite. The spectra of the minerals are dependent upon the mineral origin and its formulation. The halogenated carbonates are characterized by $\left(\mathrm{CO}_{3}\right)^{2-}$ symmetric stretching modes in the $1078-1090 \mathrm{~cm}^{-1}$ spectral range. In the case of huanghoite three Raman bands are found suggesting three non-equivalent $\left(\mathrm{CO}_{3}\right)^{2-}$ units in the huanghoite structure. This concept is supported by the observation of multiple bands in the antisymmetric stretching region. Infrared bands of huanghoite occur at 1391, 1414, 1489 and $1547 \mathrm{~cm}^{-1}$. These bands are assigned to the $\mathrm{CO}_{3}^{2-} \mathrm{v}_{3}$ antisymmetric stretching mode. Two low intensity bands at 1504 and $1432 \mathrm{~cm}^{-1}$ for bastnasite are assigned to the $v_{3}\left(\mathrm{CO}_{3}\right)^{2-}$ antisymmetric stretching mode.

The complexity of the symmetric stretching region is reflected in the $\left(\mathrm{CO}_{3}\right)^{2-}$ bending region. Four Raman bands for huanghoite are observed at $791,815,837$ and $849 \mathrm{~cm}^{-1}$ and are assigned to the $\left(\mathrm{CO}_{3}\right)^{2-} v_{2}$ bending modes. Two Raman bands at 865 and $845 \mathrm{~cm}^{-1}$ for bastnasite are assigned to the $v_{2}\left(\mathrm{CO}_{3}\right)^{2-}$ bending mode. Raman bands are observed for decrespignyite at 694, 718 and $746 \mathrm{~cm}^{-1}$ and are assigned to the $\left(\mathrm{CO}_{3}\right)^{2-} \mathrm{v}_{4}$ bending modes.

Raman spectroscopy shows both the presence of water and $\mathrm{OH}$ units in certain selected minerals from this group even though the suggested formula does not show any $\mathrm{OH}$ units being present. The Raman spectra of bastnasite show bands at 3651, 3620, 3526, 3355, 3276, 3169 and $3203 \mathrm{~cm}^{-1}$. For the mineral parisite broad bands in the $\mathrm{OH}$ stretching region with bands observed at 3516 , 3310 and $3178 \mathrm{~cm}^{-1}$. For parisite four Raman bands are observed at $3661,3517,3316$ and $3180 \mathrm{~cm}^{-1}$. A generalized formula may be written as $\left[\mathrm{Ca}(\mathrm{Ce}, \mathrm{La}, \mathrm{Nd})_{2}\left(\mathrm{CO}_{3}\right) \mathrm{F}_{2}\right]$. Raman spectroscopy suggests a general formula $\left[(\mathrm{Ce}, \mathrm{La}) \mathrm{CO}_{3}(\mathrm{OH}, \mathrm{F}) \cdot x \mathrm{H}_{2} \mathrm{O}\right]$. The presence of $\mathrm{OH}^{-}$ 
anion suggest the partial substitution of $\mathrm{F}$ by $\mathrm{OH}$ and the existence of a $\mathrm{F}-\mathrm{OH}$ series between huangoite-Ce and an undescribed mineral phase where $\mathrm{OH}$ is dominant in the structure.

Raman spectroscopy supports the concept that the position of the $\left(\mathrm{CO}_{3}\right)^{2-}$ bands is a function of the chemical composition of

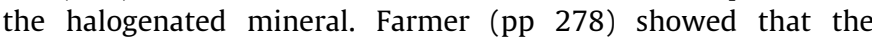
$\left(\mathrm{CO}_{3}\right)^{2-}$ symmetric stretching band varied according to the ionic radius of the cation [1]. Raman spectroscopy supports the concept that the symmetry of the carbonate anion is maintained in the structure of bastnasite, parisite and northupite, even though many minerals have significant amounts of $\mathrm{Ce}$, La or Y in the formula. The carbonate anion in the mineral hydroxybastnasite is of lower symmetry.

\section{Acknowledgements}

The financial and infra-structure support of the Discipline of Nanotechnology and Molecular Science, Science and Engineering Faculty of the Queensland University of Technology, is gratefully acknowledged. The Australian Research Council (ARC) is thanked for funding the instrumentation. The authors would like to acknowledge the Center of Microscopy at the Universidade Federal de Minas Gerais (http://www.microscopia.ufmg.br) for providing the equipment and technical support for experiments involving electron microscopy. R. Scholz thanks to CNPq - Conselho Nacional de Desenvolvimento Científico e Tecnológico (Grant No. 306287/ 2012-9).

\section{References}

[1] V.C. Farmer, Mineralogical Society Monograph 4: The Infrared Spectra of Minerals, 1974.
[2] Z. Maksimovic, G. Panto, The occurrence and genesis of the hydroxylbastnaesites from Montenegro, Yugoslavia, Bulletin - Academie Serbe des Sciences et des Arts, Classe des Sciences Mathematiques et Naturelles: Sciences Naturelles 27 (1987) 15-20. 14 plates.

[3] H. Wakita, S. Kinoshita, Bull. Chem. Soc. Jpn. 52 (1979) 428-432.

[4] Z. Maksimovic, G. Panto, Mineral. Mag. 49 (1985) 717-720.

[5] R.L. Frost, M.J. Dickfos, Spectrochim. Acta Part A Mol. Biomol. Spectrosc. 71A (2008) 143-146.

[6] R.L. Frost, M. Dickfos, Polyhedron 26 (2007) 4503-4508.

[7] R.L. Frost, M.J. Dickfos, J. Raman Spectrosc. 38 (2007) 1516-1522.

[8] G. Donnay, J.D.H. Donnay, Am. Mineral. 38 (1953) 932-963.

[9] T. Watanabe, Sci. Pap. Inst. Phys. Chem. Res. (Japan) 21 (1933) 40-62.

[10] H. Shiba, T. Watanabe, Compt. Rend. 193 (1931) 1421-1423.

[11] H.-F. Fan, Y.-Y. Chang, K.-C. Chao, Wuli Xuebao 19 (1963) 466-471.

[12] S.V. Krivovichev, S.K. Filatov, Can. Mineral. 36 (1998) 809-815.

[13] R. Miyawaki, I. Nakai, Kidorui 23 (1993) 1-21.

[14] R. Miyawaki, I. Nakai, Kidorui 25 (1994) 1-18.

[15] D. Meng, X. Wu, T. Mou, D. Li, Can. Mineral. 39 (2001) 1713-1724.

[16] D. Meng, X. Wu, M. Tao, D. Li, Mineral. Mag. 65 (2001) 797-806.

[17] Y. Ni, J.E. Post, J.M. Hughes, Am. Mineral. 85 (2000) 251-258.

[18] D. Meng, X. Wu, G. Yang, Z. Pan, Kuangwu Xuebao 15 (1995) 378-382.

[19] X. Wu, G. Yang, Z. Pan, TEM study of the syntaxies formed from the polytypes of parisite (BS) and regular mixed-layer mineral B2S, Kuangwu Xuebao 13 (1993) 214-219. 212 plates.

[20] H.H. Adler, P.F. Kerr, Am. Mineral. 48 (1963) 839-853.

[21] M.V. Akhmanova, L.P. Orlova, Geokhimiya (1966) 571-578.

[22] R.L. Frost, S. Bahfenne, J. Raman Spectrosc. 42 (2011) 219-223.

[23] R.L. Frost, S. Bahfenne, J. Cejka, J. Sejkora, J. Plasil, S.J. Palmer, E.C. Keeffe, I, Nemec, J. Raman Spectrosc. 42 (2011) 56-61.

[24] S.J. Palmer, R.L. Frost, J. Raman Spectrosc. 42 (2011) 224-229.

[25] M.P. Smith, P. Henderson, L.S. Campbell, Geochim. Cosmochim. Acta 64 (2000) $3141-3160$.

[26] K. Nakamoto, Infrared Spectra of Inorganic and Coordination Compounds, 1963.

[27] H. Fan, K. Tao, Y. Xie, K. Wang, Yanshi Xuebao 19 (2003) 169-172.

[28] W. Hong, S. He, S. Huang, Y. Wang, H. Hou, X. Zhu, Guangpuxue Yu Guangpu Fenxi 19 (1999) 546-549.

[29] I.V. Aleksandrov, V.I. Ivanov, L.A. Sin'kova, Zapiski Vserossiiskogo Mineralogicheskogo Obshchestva 94 (1965) 323-326. 